\title{
Media Balok Kata (BTA) to Stimulate the Ability of Reading Word Recognition for Student with Learning Problem
}

\author{
Nunur Nuraeni, Murni Winarsih, Riana Bagaskorowati \\ Special Education Department \\ Universitas Negeri Jakarta, UNJ \\ Jakarta, Indonesia \\ nunurnuraeni21@gmail.com
}

\begin{abstract}
This development aims to produce an instructional media that can be used to stimulate ability of reading word recognition for student with learning problems on class IV. The model used for this development is ADDIE from research and development method. ADDIE has 5 steps, which are analyses, design, development, implementation and evaluation. The overall average of product evaluation is $85 \%$ and the media was tested on 3 students from 4th grade elementary school. The result shows that media BTA can help stimulating reading word recognition. The implication of this development for students with learning problem in class IV is expected to increase the motivation and the interest to read. Media Balok Kata (BTA) can help teacher to teach about reading a vocabulary. Besides, BTA is expected to be a consideration in developing a product of other instructional media.
\end{abstract}

Keywords-instructional media; balok kata; vocabulary; learning problems.

\section{INTRODUCTION}

Reading is an activity to interpret a symbol in form of writing to find out information. Besides, reading can also be interpreted as one of the activities that can be used to complete or to do something like learning or knowing about something. Reading is a complex activity because it requires several abilities such as: visual perception and differentiating sounds.

There are two types of reading ability, which are reading word recognition and reading comprehension. Reading word recognition is an initial understanding in reading such as knowing vocabulary and phoneme analysis to describe activities in developing meaning in details. From the explanation, it can be seen that reading is something important for life because by reading people can learn many things. Especially for students, reading ability is the basic foundation for gaining knowledge and or learning the existing lessons because most of the learning resources are writings that must be read. To have reading skills, it is necessary for them to go through the stages of development.
Not infrequently, there are still students who still have problems passing the initial reading stage. As a result of observations that have been made by researchers in grade 4 of SDN Jatinegara Kaum Pagi 14, there are students who already know the letters of the alphabet, and read the words with consonant-vowel-consonants and vowel-vowel patterns well. However, they still get difficulties reading words with consonant-consonant-vowel patterns and consonant-vowels.

Based on observations made during learning process in the classroom, there are several things that cause the problem. Researchers see less effective learning reading because of the lack of learning media. The media used was in the form of alphabet letter posters so that students were less motivated to learn to read. On the other hand, researchers also found other factors that became obstacles such as low economic constraints so that students did not do additional exercises to read at home.

By looking at the constraints above and the basic abilities possessed by students, researchers want to do the development of learning media by creating a BTA media to stimulate the initial stage of reading ability for students with learning problems. This BTA media was developed from the Uno stack game.

Based on the constraints and the basic abilities of students, researchers want to develop learning media by creating Media Balok Kata to stimulate the ability of reading word recognition for students with learning problems. This Media Balok Kata was developed from the Uno stack game.

\section{LITERATURE REVIEW}

Briggs (1979) in reference [1] explained that instructional media are physical tools to deliver subject matter in the form of books, films, video recordings, and so on. The media can also play a role to provide incentives for students to be more active in the learning process. Meanwhile, Rudy Bretz divides the media based on its main elements, namely sound, visual and motion. Besides, Bretz distinguishes between broadcast media (telecommunication) and recording media (recording). Thus, the media according to Brentz's taxonomy are grouped 
into 8 categories: (1) audio visual motion media, (2) Silent audio visual media, (3) semi-moving audio media, (4) motion visual media, (5) visual Media, (6) semi-motion media, (7) audio media, and (8) print media [1].

Then reference [2] explained that the media is functioned as a mean to achieve the learning objectives; therefore, the information contained in the media must be able to involve students, either in their mind or in the form of real activities, so, learning can occur. The material must be designed more systematically and psychologically, and reviewed in terms of learning principles in order to prepare effective learning instructions. Besides being fun, learning media must be able to provide a pleasant experience and meet the individual needs of students, because each student has different abilities [2].

Reading is a process that is carried out and used by the reader to get the message to be conveyed by the author through the media of words or language [3]. Harris and Siplay divide the development of reading into 5 stages, namely the development of reading readiness, the reading word recognition stage, the stage of developing reading or speed reading skills, the expansion of reading skills, and the smoothing of reading skills.

The stage of developing reading readiness means that the child is mentally ready to read which in general, the readiness of children to read is around the age of 6 years. After that, the reading word recognition phase generally starts in the early grade of elementary school, but there are children who start it earlier in kindergarten and no later than when the child sits in grade 2 of elementary school. Furthermore, the stage of developing reading skills begins in grade 3 of elementary school. The expansion stage of reading skills aims to develop children's ability to read comprehensively. Finally, the stage of refining reading skills is usually done in high school. During this time, reading activities increased not only in terms of the number of readings, but also in terms of the level of difficulty [4].

Learning problems are the circumstances of someone who experiences problems in learning because of conditions from the external aspects of the individual such as motivation, family acceptance of the $\mathrm{study}$, the delivery of material carried out by the teacher, the suitability of the material and also the time given which can also have an impact on learning [5].

Meanwhile, reference [6] explained that the problem of learning is the condition a person experiences a problem in learning so that it affects his performance in the classroom not because of biological conditions or brain problems but problems from the environment such as learning methods, allocation of learning time, environment and also motivation [6].

As for the relevant research study, the research about vocabulary video media was conducted by Dwipuspa to stimulate the initial reading ability of deaf students in class II SDLB. The differences found in Dwipuspa's research were subject and material. Dwipuspa's research subjects were children with hearing impairment while the subject researchers were children with learning problems. Dwipuspa used video while the researcher used beams and word cards. Similar research was also conducted by Rahmah, PLB UNJ 2012 with the title Increasing the Ability of Indonesian Vocabulary through the Use of Flip Chart Media for Deaf Students in Class III SLBN 2 South Jakarta. The research conducted by Rahmah used the classroom action research while the researcher used the ADDIE model research methodology. Besides, the difference between Rahmah and researchers is the subject and the material. Rahmah's research subjects were deaf while the research subjects were children with learning problems. Likewise, the difference was also found in terms of the material use that Rahmah used image cards.

\section{METHOD}

The method used in making BTA is an innovative method of work. This work is based on innovation and research development based on media needs for students with learning problems by following the steps of the ADDIE model research.

The ADDIE model is one of the systematic learning design models. The ADDIE model consists of five steps in the implementation of research and development strategies, namely the analysis stage, the design stage, the development phase, the implementation phase and the evaluation stage.

Based on these explanations, it can be concluded that innovative work research is to produce a product. In this study, the product produced in the form of learning media.

This research was conducted from February 2018 to July 2018 in the even semester of 2017/2018 at SDN 14 Jatinegara Kaum Pagi. Respondents from this study were grade 4 students who were suspected of having learning problems, especially those who could read the beginnings b u t n o t s o smoothly to read words with the V-V-K and or $\mathrm{K}-\mathrm{K}-\mathrm{V}$ pattern.

In addition, to conduct the trials on respondents who have been selected, previously, the media that has been made was validated in advanced by 3 experts in accordance with their field of expertise, namely media experts by Mr. Cecep Kustandi, M.Pd as a lecturer from the Education Technology Department, Jakarta State University, the material expert by Mrs. Imelda Rentaida, S.Pd as the class teacher from the respondent, and finally a learning problem expert by Mrs. Leliana Lianty as a lecturer in Special Education.

In this study, results in the form of data were used as a basis for drawing conclusions. Data in this study were collected using questionnaires, interviews and observations. Questionnaires and interviews were used for media experts, learning problem experts and material experts in assessing the suitability of the material with BTA learning media produced for students with learning problems at SDN 14 Jatinegara Kaum Pagi and also used for giving opinions on product development. Furthermore, the observation sheet was used to find out the strengths and weaknesses of BTA media when they utilized the media. In addition, researchers also conducted interviews to see their interest after using the BTA media. The analysis technique used to process data obtained through questionnaires is in the form of descriptive 
percentages. The formula used to calculate the percentage of each subject is as follows:

$$
\mathrm{P}=\mathrm{F} / \mathrm{N} X 100 \%
$$

\section{Information:}

$$
\begin{aligned}
& \mathrm{P}=\text { the result of the answer (percentage) } \\
& \mathrm{F}=\text { frequency of answers } \\
& \mathrm{N}=\text { number of respondents }
\end{aligned}
$$

Interpretation of Data Analysis Results of Expert Review Assessment is presented in Table 1.

TABLE I. INTERPRETATION OF DATA ANALYSIS RESULTS OF EXPERT REVIEW ASSESMENT

\begin{tabular}{|l|l|l|}
\hline \multicolumn{1}{|c|}{$\begin{array}{c}\text { Achievement } \\
\text { Level }\end{array}$} & \multicolumn{1}{|c|}{ Qualification } & \multicolumn{1}{c|}{ Note } \\
\hline $86 \%-100 \%$ & Very good & $\begin{array}{l}\text { No need to } \\
\text { be revised }\end{array}$ \\
\hline $70 \%-85 \%$ & Good & $\begin{array}{l}\text { Revised as } \\
\text { Needed }\end{array}$ \\
\hline $55 \%-69 \%$ & Enough & $\begin{array}{l}\text { Revised } \\
\text { Enough }\end{array}$ \\
\hline $\begin{array}{l}\text { Below } \\
55\end{array}$ & Less & $\begin{array}{l}\text { Many } \\
\text { revised }\end{array}$ \\
\hline
\end{tabular}

\section{RESULT AND DISCUSSION}

The product name from the results of the development of this innovative work is "BALOK KATA (BTA)". BTA media is created and is developed to stimulate the initial reading ability of students with learning problems. The media consists of blocks containing alphabet letters from A-Z and illustrated word cards intended to support the BTA game.

This BTA product is also equipped with a guidebook on the use of media in a language that is easily understood by teachers and users. This media was developed as a learning media in the form of games for children with learning problems. This media produced aims to stimulate the ability to teach reading in children with learning problems. Before starting the activities, there was explanation about the usefulness of BTA media and the function of each part in BTA media. After all stages could be understood, students could start using BTA media.

The development of BTA media referred to the ADDIE development model. The limitation of the research included the stages of analysis that the researcher found that there were grade 4 students who have not been able to read especially with the letter pattern C-C-V and V-V-C. In addition, researchers found that the lack of motivation in learning to read early because of the learning media which was used at the beginning of the learning process of reading. Next was the design stage; at this stage, researchers made the initial design for the BTA media. Researchers began designing the beam design starting from choosing the wood material, beam size, color and letters to be used. Besides, the researchers also made a word card design. The researcher chose the word to be used on the word card, designed the image and selected the font size that would be used. In addition, at this stage it was also planned that media evaluation would be carried out by experts by making an assessment grid for BTA media. Then, the development stage in the development of this product began with the collection of materials, processing of materials, and finally the production. The materials were collected in the form of wood as the main material of the beam, paper for word cards and manuals, plywood for the box of blocks and word cards. After the material has been collected, BTA media product was produced in accordance with the initial design that has been made by researchers.

The next step was the validation and testing phase of the word blocks that have been produced. The initial validation was carried out and then was revised, which was then evaluated by 3 experts namely media experts, material, and learning problems. The word blocks product as a learning medium was essential to be validated. Validation was carried out in two stages: step 1 was validation by material experts, media and learning problems. In this stage, the product feasibility data and expert advice were obtained.

The suggestion was then used for the revision of stage 1 . The results of the revision were used to test the feasibility of the media used in the trial in the form of student responses to learning media in the form of word blocks.

\section{A. Product Trial Results}

The results of the trial recapitulation of learning problem experts, material experts and media experts on the BTA learning media as a whole are shown as follows

TABLE II. EXPERT REVIEW

\begin{tabular}{|l|l|l|l|l|}
\hline \multicolumn{1}{|c|}{ Respondents } & $\begin{array}{c}\text { Revision } \\
\mathbf{1}\end{array}$ & $\begin{array}{c}\text { Revision } \\
\mathbf{2}\end{array}$ & Average & Qualification \\
\hline $\begin{array}{l}\text { Learning } \\
\text { Problem } \\
\text { Expert }\end{array}$ & 79 & 94 & 86,5 & Very Good \\
\hline $\begin{array}{l}\text { Expert } \\
\text { Materials }\end{array}$ & 79 & 85 & 82 & Good \\
\hline Media Expert & 81 & 94 & 87,5 & Very Good \\
\hline $\begin{array}{l}\text { Overall } \\
\text { Average }\end{array}$ & 79,6 & 91 & 85,3 & Good \\
\hline
\end{tabular}

According to descriptive frequency statistics, the results were obtained in form of percentages obtained through the interpretation of quantitative results into qualitative through descriptive narratives with the following categories:

$$
\begin{aligned}
& 86 \%-100 \%=\text { Very good } \\
& 70 \%-85 \%=\text { Good } \\
& 55 \%-69 \%=\text { Enough } \\
& \text { Below } 55 \%=\text { less }
\end{aligned}
$$


Furthermore, the frequency of success achieved by this study was good, with $85 \%$ success rate based on the results of the reviews of experts. It can be concluded that BTA media still needs to be fixed.

The similar result can be found in research of reference [7], that the BTA increased the kindergarten students' ability in mathematics. Students' ability increased from 66.8 in cycle I, 73.3 in cycle II, and $84 \%$ in cycle III. Reference [8] also showed the research result that the BTA increased the ability of kindergarten students to recognize letter. Moreover, reference [9] found that BTA increased the student creativity. After utilizing BTA media, students' creativity increased from $67 \%$ to $91 \%$.

\section{CONCLUSION}

The media produced in this study is the word blocks media. This media is used to stimulate the initial reading ability. This media development was validated by media expert, material expert and learning problem expert. Furthermore, the products that have been revised according to the results of the validation by experts were then tested on 4th grade students at SDN Jatinegara Kaum 14 Pagi to get the results that the BTA media can be utilized and facilitate students in stimulating the initial reading ability of students with learning problems in grade 4 .

\section{SUGGESTION}

It is suggested for the teacher to use the BTA media to make it easier to learn reading especially at the beginning of the material of reading words with a letter pattern consonantvowel and vowels. Moreover, the teacher is expected to be more creative in the learning process and can motivate students to learn. For other researcher who will develop similar learning media, the media produced must be in accordance with the characteristics of the students. In addition, the material used must be truly in accordance with the problems faced by students. This is very important to concern the quality of the media_developed. Furthermore, the researcher is expected to be able to cooperate with other parties who are experts in their fields in developing learning media. This is useful to make the process of developing learning media more effective and efficient in terms of time, material and other things. BTA media can also be developed and modified to stimulate other learning such as writing and counting.

\section{REFERENCES}

[1] . Indriana, Ragam Alat Bantu Media Pengajaran,Yogyakarta: DIVA Press, 2011.

[2] C. Kustandi, and B. Sutjipto, Media Pembelajaran Manual dan Digital. Bogor: Ghalia Indonesia, 2011.

[3] B. Tarigan, "Pendidikan jasmani, olahraga dan kesehatan Adaptif,"unpublished

[4] M. Abdurrahman, Pendidikan Bagi Anak Berkesulitan Belajar. Jakarta: PT Asdi Mahasatya, 2010

[5] V. Sharon, and C.S. Boss, Strategy Studies with Learning and Behavior Problems. New Jersey: Phoenix Color Corp, 2009.

[6] Peter, What Teachers Need to Know about Reading and Writing difficulties. Australia: ACER Press, 2008.

[7] A.Cahyaningrum, "Meningkatkan kemampuan berhitung melalui media balok pada anak kelompok B di TK Guworejo 2 Karang Malang Kabupaten Sragen tahun ajaran 2013/2014," Bachelor Thesis, Faculty of Teacher Training and Education, Muhammadiyah University, Surakarta, 2013.

[8] S. L. Andayani, "Penggunaan media balok huruf pada kemampuan mengenal huruf anak usia 5-6 tahun di tk beringin raya bandar lampung tahun ajaran 2014/2015," Bachelor Thesis, Faculty of Teacher Training and Education, Lampung University, Lampung, 2015.

[9] Izartin, "Penerapan Metode Bermain Balok untuk Meningkatkan Kreatifitas Anak di PAUD Negeri Pembina Palu Utara,” Jurnal Kreatif Tadulako Online, vol. 4 No. 7, pp. 1-7, 2016. 